\title{
Oligochaeta (Annelida) of Lake Kurilskoe, Kamchatka Peninsula
}

\author{
Tarmo Timm ${ }^{1}$ and Tatyana L. Vvedenskaya ${ }^{2}$ \\ ${ }^{1}$ Centre for Limnology, Institute of Agricultural and Environmental Sciences, \\ Estonian University of Life Sciences, 61101 Rannu, Tartumaa, Estonia \\ E-mail: tarmo.timm@emu.ee \\ ${ }^{2}$ Kamchatkan Branch, Pacific Institute of Fisheries and Oceanography, \\ Naberezhnaya 18, 683002 Petropavlovsk-Kamchatskii, Russia \\ E-mail: tatyanakam@mail.ru
}

(Received 27 September 2005; Accepted 8 April 2006)

\begin{abstract}
Lake Kurilskoe ( $77.05 \mathrm{~km}^{2}$, maximum depth $316 \mathrm{~m} ; 104 \mathrm{~m}$ above sea level) is an oligotrophic caldera lake on the southern Kamchatka Peninsula, Russian Far East. The littoral zone is devoid of macrovegetation. During a hydrobiological study in 1994-1998, 43 taxa of oligochaetes were found, 26 of them identified to the species level. The littoral zone was inhabited mostly by the Enchytraeidae, Lumbricillus pagenstecheri (Ratzel, 1869), L. arenarius (Michaelsen, 1889), Mesenchytraeus kuril Healy and Timm, 2000, Marionina charlottensis Coates, 1980, and M. klaskisharum Coates, 1983. Propappus arhynchotus Sokolskaya, 1972 and Haplotaxis gordioides (Hartmann, 1821) were also sometimes abundant. Naidinae included a large form of Nais communis Piguet, 1906, together with $N$. variabilis Piguet, 1906, N. pardalis Piguet, 1906, and Pristina aequiseta Bourne, 1891. Tubificidae s. s. and Lumbriculidae preferred the deeper littoral and sublittoral areas of the lake. The profundal zone was inhabited by Embolocephalus kurenkovi (Sokolskaya, 1961), Limnodrilus profundicola (Verrill, 1871), Tasserkidrilus americanus (Brinkhurst and Cook, 1966), and Styloscolex opisthothecus Sokolskaya, 1969, all in great abundance. Many oligochaete species widely distributed in nearby regions were not found in this lake.
\end{abstract}

Key Words: Oligochaeta, faunal survey, Lake Kurilskoe, Russian Far East, Kamchatka, caldera lake, biogeography.

\section{Introduction}

The Kamchatka Peninsula $\left(350,000 \mathrm{~km}^{2}\right)$ is a relatively pristine region of Russia. The lakes and rivers of Kamchatka are mostly oligotrophic but fertilized with ash from eruptions of the nearby volcanoes. These aquatic habitats serve as a spawning ground for Pacific salmon species and also shelter many animal species endemic to the area. The freshwater oligochaete fauna of Kamchatka was surveyed previously by Sokolskaya (1983), who also referred to a small collection from Lake Kurilskoe that had been identified by Michaelsen (1929). The hydrobiology of Lake Kurilskoe was studied during 1994-1998 by the Kamchatkan Branch of the Pacific Institute of Fisheries and Oceanography because the lake is an important spawning ground for sockeye salmon. This present paper summarizes the findings of a 
limited survey of the oligochaete fauna collected during that study.

\section{Material and Methods}

\section{Study area}

Lake Kurilskoe (surface area $77.05 \mathrm{~km}^{2}$, maximum depth $316 \mathrm{~m}$, volume 14.6 $\mathrm{km}^{3}$ ) is situated in an old volcanic caldera near the southern end of the Kamchatka Peninsula, at $51^{\circ} 27^{\prime} \mathrm{N}, 157^{\circ} 03^{\prime} \mathrm{E}, 104 \mathrm{~m}$ above sea level (Fig. 1). The present lake was formed about 8,000 years ago (Zubin et al. 1982). Lake Kurilskoe is fed by 25 alpine
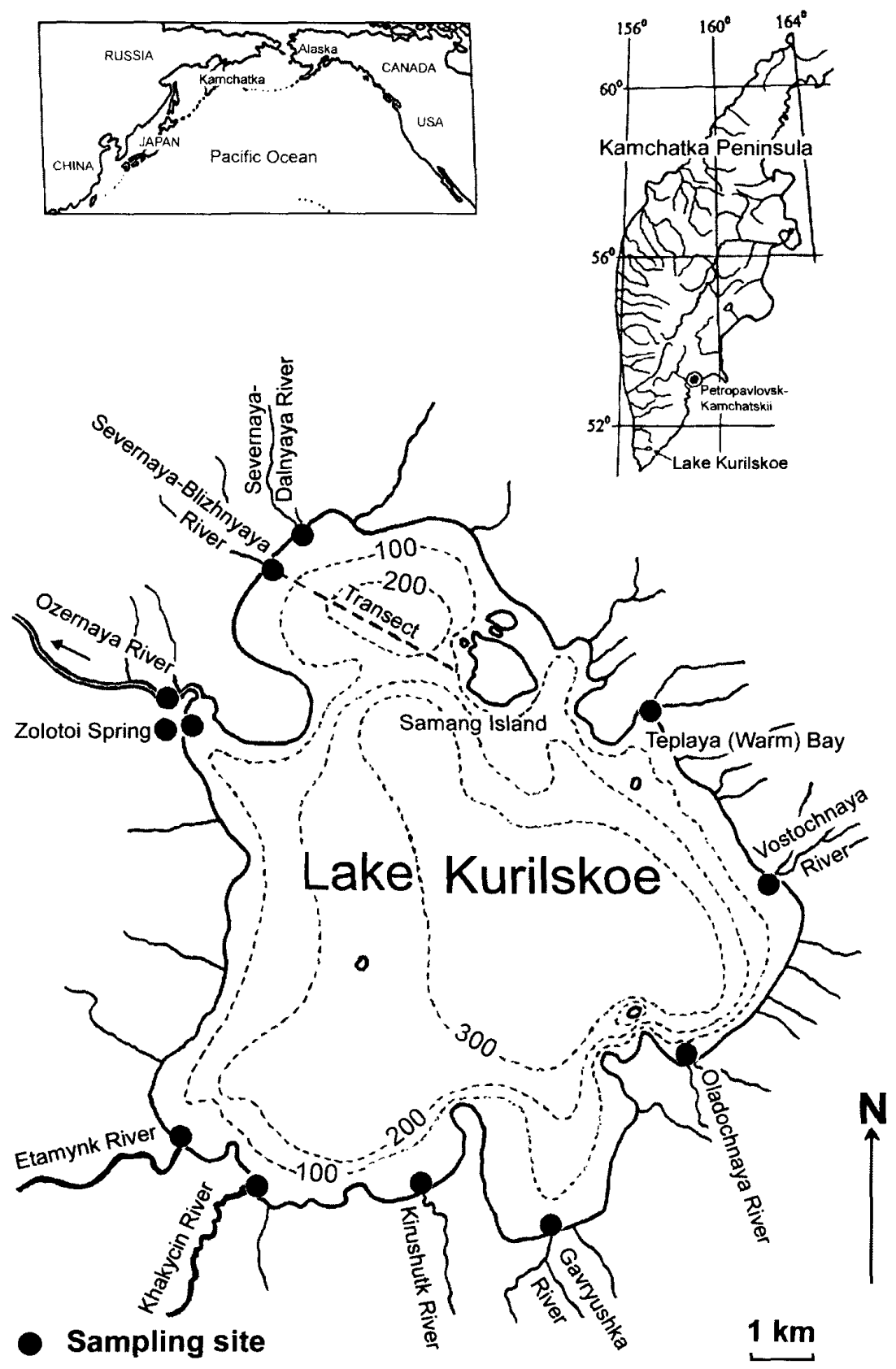

Fig. 1. Location of Lake Kurilskoe and the sampling sites. 
streams; its outflow, the Ozernaya River, flows into the Sea of Okhotsk $48 \mathrm{~km}$ away. The lake is dimictic and oligotrophic, with a Secchi disk transparency of about 10 m. The ice cover usually lasts from February to April. The water temperature does not rise above $12^{\circ} \mathrm{C}$ except in Teplaya Bay, where thermal springs can raise the temperature to $27^{\circ} \mathrm{C}$. A thermocline can occur at depths between $30-150 \mathrm{~m}$, but the hydrochemical stratification remains weak. The combined concentration of major ions is about $70 \mathrm{mg} / 1$ with bicarbonate, calcium, and magnesium ions as the dominant components. The water is slightly enriched with ash from eruptions of nearby volcanoes. The concentration of silica is high (up to $8 \mathrm{mg} / \mathrm{l}$ ) while that of phosphate phosphorus is very low $(2-8 \mu \mathrm{g} / \mathrm{l})$; the dissolved oxygen concentration ranges from 10-14 mg/l (Stepanov 1986; Ukolova and Sviridenko 2002; Milovskaya 2004).

The bottom of the narrow littoral zone (arbitrarily defined as the upper $5 \mathrm{~m}$ ) consists of gravel, stones, and sand. Apart from lush algal periphyton covering stones (particularly along the wind-protected western shore) from July until September, macrovegetation is lacking. Muddy sand and gravel bottoms dominate the sublittoral zone of the lake (depth 5-20 m); the deeper, profundal areas are covered with mud.

The outflowing Ozernaya River is $60 \mathrm{~m}$ wide and up to $1 \mathrm{~m}$ deep near its beginning, with a water discharge of $15-50 \mathrm{~m}^{3} / \mathrm{sec}$ and a current velocity of $0.1-0.2 \mathrm{~m} / \mathrm{sec}$; the bottom consists of sand with some boulders and tufts of water moss. The Zolotoi Spring is a very tiny but torrential and cool brook (flow velocity $0.6-0.8 \mathrm{~m} / \mathrm{sec}$, water temperature up to $9^{\circ} \mathrm{C}$ in August) with a stony bottom, discharging into the lake.

The phytoplankton of the lake is dominated by the diatom Aulacoseira italica (Ehrenberg) Simonsen. The zooplankton consists of a limited number of copepod, cladoceran, and rotifer species, with a mean biomass of $15 \mathrm{mg} / \mathrm{m}^{3}$ (Milovskaya et al. 1998). The anadromous sockeye salmon, Oncorhynchus nerka (Walbaum, 1792), dominates the fish fauna. Artificial fertilization of the lake with phosphates in the 1980s was followed by an increase in the productivity of diatoms (Milovskaya et al. 1998).

The average abundance of total zoobenthos (including meiobenthos), determined at several shallow-water sites, ranged from 2,494 to 69,384 individuals $/ \mathrm{m}^{2}$ in the summer of 1996, with the highest biomass measured at a site near the outflow. The wet biomass varied between 0.1 and $4.3 \mathrm{~g} / \mathrm{m}^{2}$. In the Ozernaya River, $100 \mathrm{~m}$ from the source, 128,713 individuals $/ \mathrm{m}^{2}$ were recorded with a biomass of $20.6 \mathrm{~g} / \mathrm{m}^{2}$. The Zolotoi Spring yielded 46,208 individuals $/ \mathrm{m}^{2}$ in 1996 with a biomass of $3.4 \mathrm{~g} / \mathrm{m}^{2}$. Chironomidae and Oligochaeta dominated in biomass at most of the shallow-water stations. The percentage of chironomids decreased drastically with depth; the meiobenthic ostracod, Cytherissa lacustris (Sars, 1863), and nematodes became more abundant in the sublittoral and profundal zone (Vvedenskaya and Travina 2001).

\section{Sampling}

Zoobenthos was collected by the second author from the sites shown in Fig. 1. In June-July 1994, three sites were sampled: 1) the shallowest littoral zone near the outflow; 2) the outflowing river $50 \mathrm{~m}$ downstream of the source; and 3) the spring brook. In 1996-1998 the collecting season lasted from mid-June to mid-September, 
with sampling every 10 days at up to 10 shallow-water $(0.3-0.5 \mathrm{~m})$ sites around the lake, one site on the river, and one site in the brook. In addition, samples were collected twice in 1997 and twice in 1998 from different depths (1-198 m) along a transect located between a northwestern site (Severnaya-Blizhnyaya) and Samang Island. Altogether, this study included oligochaetes obtained from 81 samples from shallow littoral areas of the lake, 58 samples from other lake areas ranging in depth from 1 to $198 \mathrm{~m}, 18$ samples from one site in the river, and 15 samples from the brook.

Samples from the shallow littoral sites in the lake and from the brook were obtained with a $40 \times 30 \mathrm{~cm}$ Levanidov trap (sampling area: $1,200 \mathrm{~cm}^{2}$ ) (Levanidov 1976). Those from the deeper littoral and sublittoral sites, and from the river, were taken with a small $\left(250 \mathrm{~cm}^{2}\right)$ Petersen grab. The deepest, profundal sites, beginning at $30 \mathrm{~m}$, were sampled with a $14.5 \mathrm{~cm}^{2}$ corer. Samples were washed in the field on a silk sieve (34-38 threads $/ \mathrm{cm}$ ), and the residue was preserved in $4 \%$ formalin. The animals were sorted from preserved samples using a dissecting microscope. The oligochaetes were studied by the first author, mostly as whole mounts in glycerine. Some specimens were mounted in Canada balsam, while others were embedded in paraffin and sectioned. Voucher specimens are deposited in the oligochaete collection of the Centre for Limnology, Estonia.

\section{Results}

In total, 28,753 specimens of Oligochaeta were collected in 172 samples. Twenty-six taxa were identified to the species level; 17 other oligochaete taxa remained unidentifiable beyond the family, subfamily, or genus level, because the specimens were either incomplete (fragments only) or sexually immature (Table 1). Four of them (Tubificidae gen. sp. No. 1 and No. 2, Mesenchytraeus sp. No. 2, and Lumbriculidae gen. sp.) were dissimilar to any known species and could very well represent species new to science. Unfortunately, the available material was insufficient for formal descriptions. A small part of these data, including the description of Mesenchytraeus kuril Healy and Timm, 2000, has already been published (Timm 1999a; Healy and Timm 2000).

\section{Taxonomic remarks}

The former family Naididae is treated here as a subfamily of Tubificidae, following Erséus and Gustavsson (2002). Nais communis Piguet, 1906 was the most common naidine collected from all habitats, with a few individuals met even in the profundal. Specimens of $N$. communis collected during this study were always much larger than those of its congeners: about $5 \mathrm{~mm}$ long and $0.3-0.5 \mathrm{~mm}$ wide under the cover glass (Fig. 2a, d-f). In comparison, specimens of $N$. variabilis Piguet, 1906 were always much smaller (1.5-3 mm long) (Fig. 2b, g-i) than N. communis, while those of $N$. pardalis Piguet, 1906 were intermediate in size (Fig. 2c, $\mathrm{j}-1)$. Some small individuals, otherwise similar to $N$. variabilis, exhibited single characteristics of $N$. communis (gradual dilatation of stomach, or asymmetrical teeth in needle chaetae). Differences in the shapes of the anterior and posterior ventral chaetae were minimal in $N$. variabilis, all possessing a slightly longer upper tooth (Fig. 2h-i). Unlike typical European specimens, the hair chaetae of $N$. 


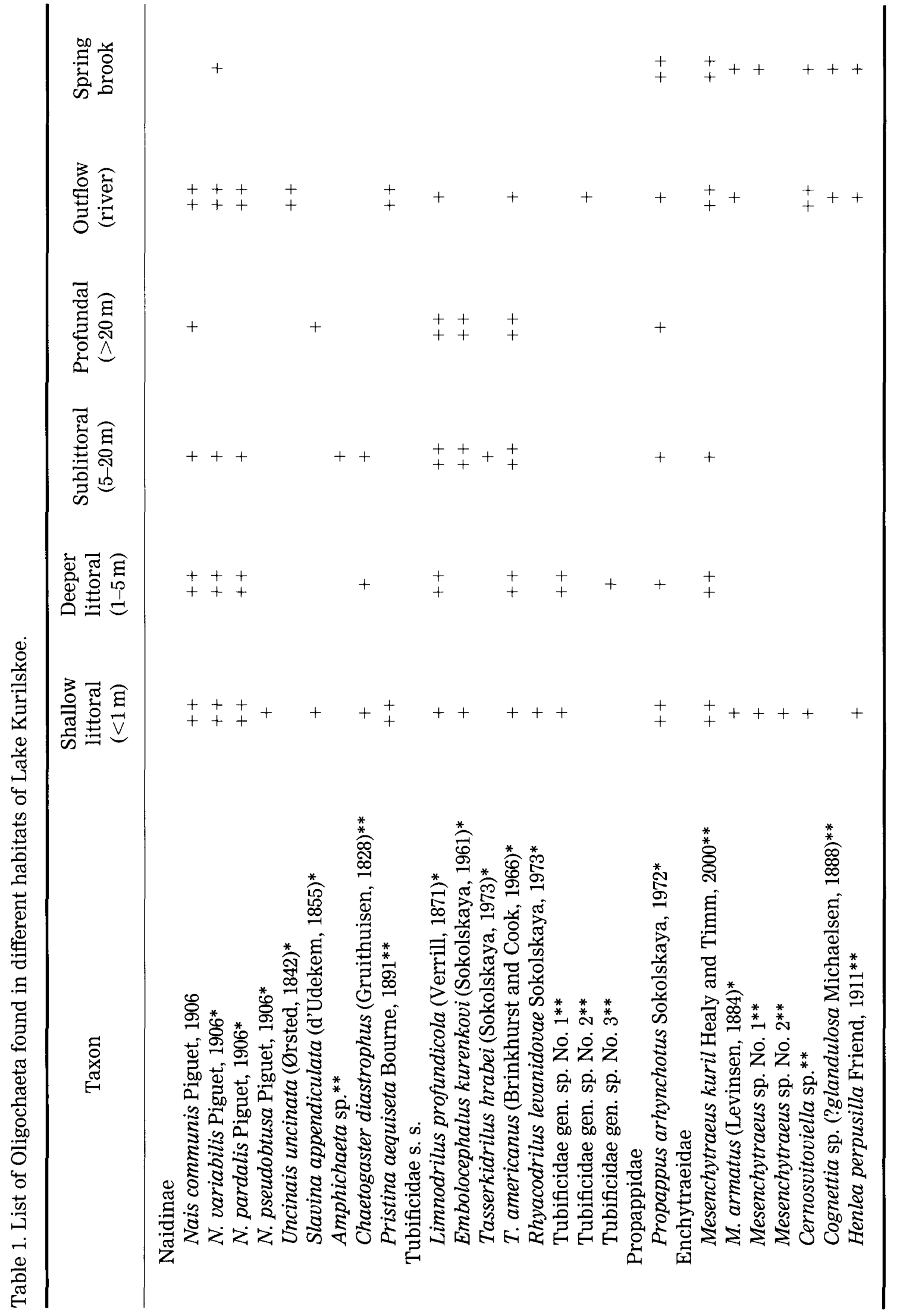




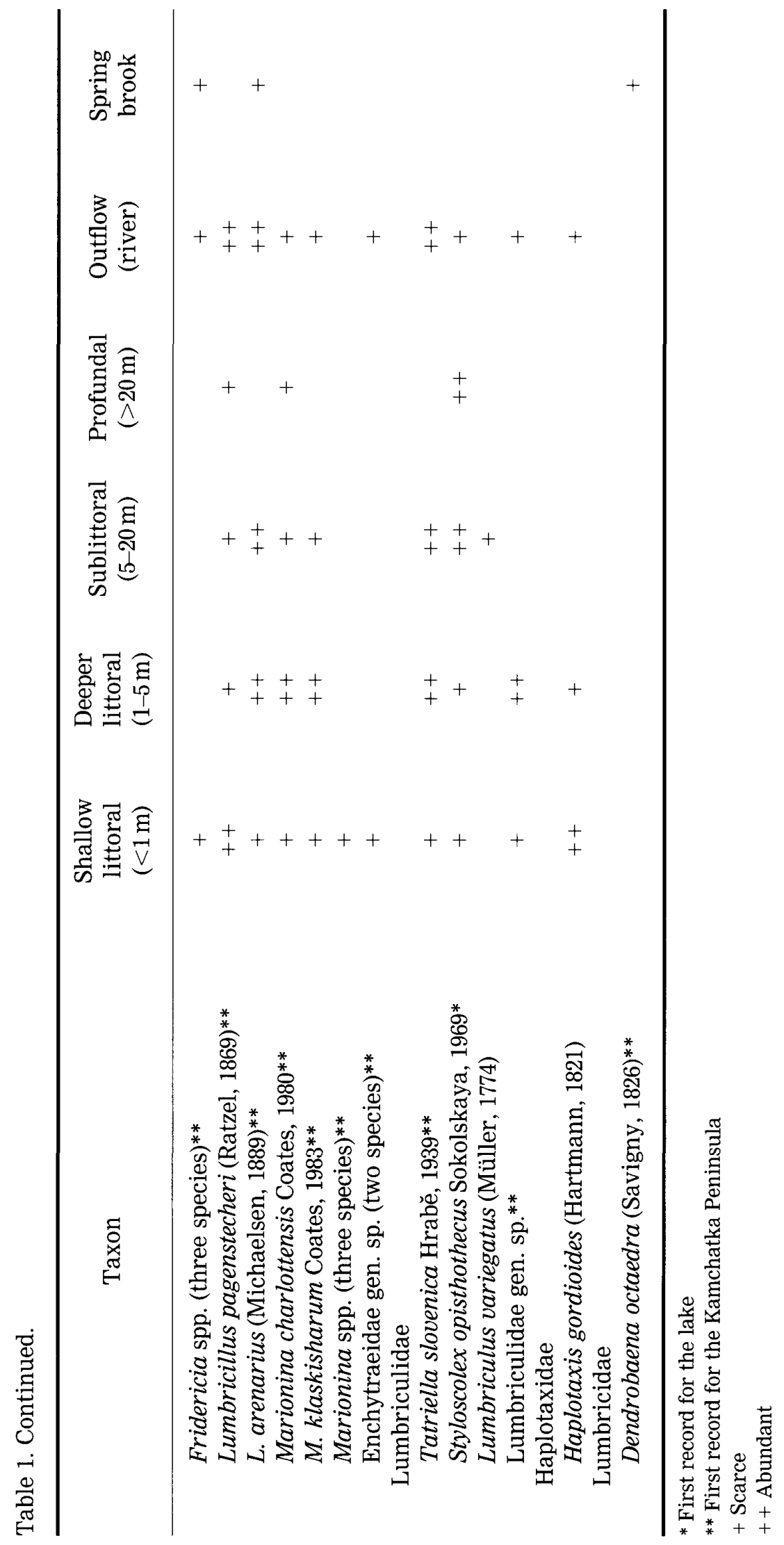



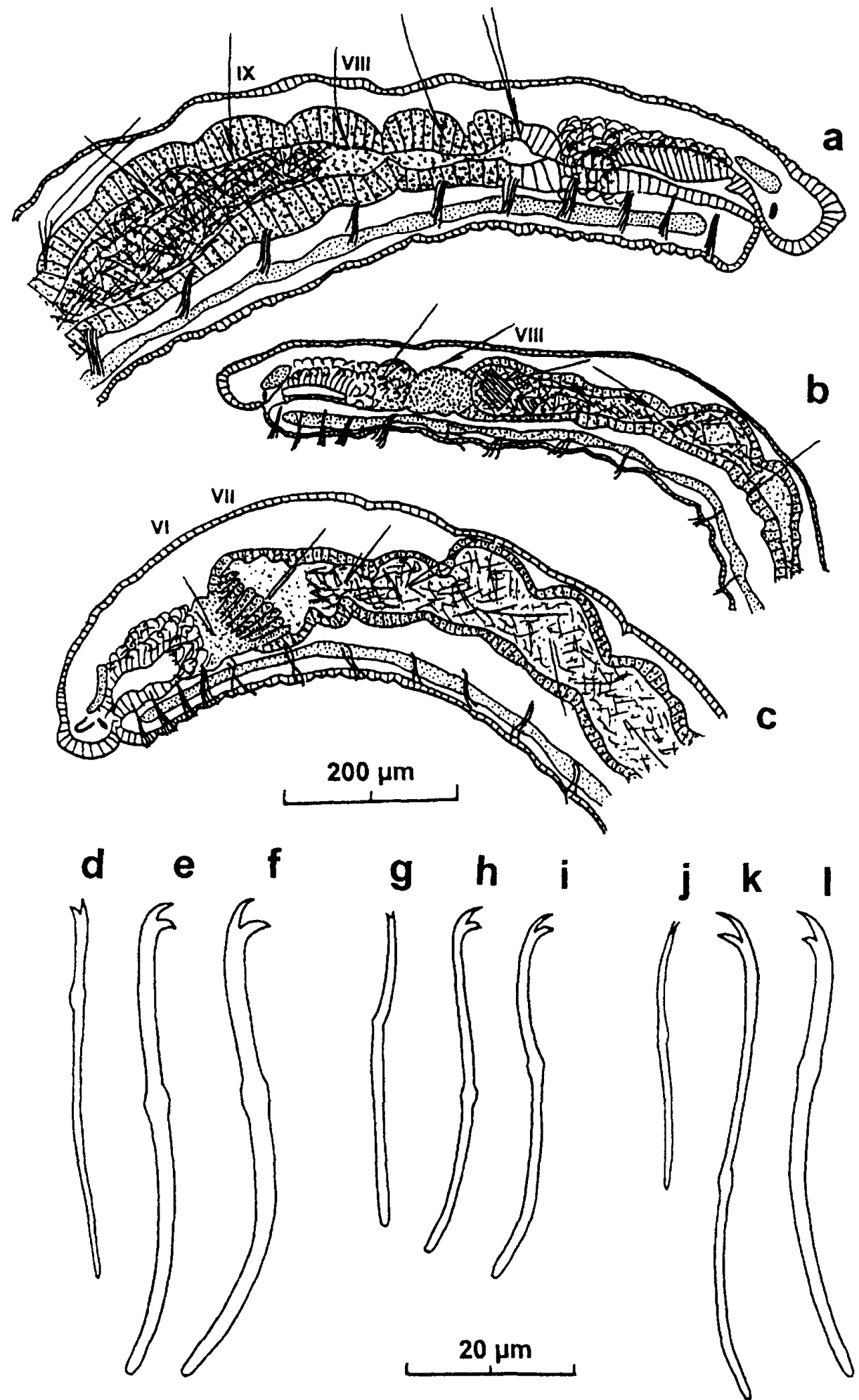

Fig. 2. Three species of Nais from Lake Kurilskoe. a, d-f, Nais communis; b, g-i, Nais variabilis; c, j-I, Nais pardalis. a-c, Anterior end; d, g, j, needle chaeta; e, h, k, ventral chaeta from anterior end; f, i, l, ventral chaeta from midbody. Body segments numbered with Roman numerals in $\mathrm{a}-\mathrm{c}$. 
variabilis collected during this study were rarely longer than the body diameter. Specimens of $N$. communis and Uncinais uncinata (Ørsted, 1842) (the latter collected only from the river) repeatedly showed an abnormality in that the dorsal chaetae began on segment V rather than VI. Pristina aequiseta Bourne, 1871 was most common at a site in Teplaya Bay that was influenced by thermal springs, and the specimens always resembled the typical form, with enlarged ventral chaetae on segment IV. The latter observation is different from those of Harman (1980), as well as from those of the first author-that the foreli form (devoid of enlarged chaetae) of $P$. aequiseta is characteristic of softer water and is more common in northern regions.

Specimens of the tubificid Embolocephalus kurenkovi (Sokolskaya, 1961) [=Spirosperma (Embolocephalus) kurenkovi of Sokolskaya 1983] collected during this study had huge spermathecal ampullae occupying most of the cavity of segments XI-XIII, sometimes filled not with spermatozeugmata but with long, irregular bundles of filiform spermatozoa, while the other ampulla could either be empty or contain normal spermatozeugmata.

Tasserkidrilus americanus (Brinkhurst and Cook, 1966) (=Tubifex kessleri americanus of Sokolskaya 1973, 1983) had, in this material, usually only one to two (rarely three) hair chaetae per bundle, versus tree to four as described by Brinkhurst and Cook (1966) and Sokolskaya (1973, 1983), and zero to four by Holmquist (1985). No barbed hair chaetae were noted. The atrium was tubular and consisted of histologically different portions, similar to the description and figures of Holmquist (1985). The spermathecal ampulla of $T$. americanus has been shown as bipartite (as in some of its congeners) by Holmquist (1985), but simple by Sokolskaya $(1973,1983)$. Both types were observed in Lake Kurilskoe material, but the ampullae were usually simple, even sphaerical. Internal projections of the ampullar epithelium (seen in specimens collected during this study as concentric ridges around the beginning of the spermathecal duct; Fig. 3a) were depicted, although not mentioned specifically, also by Sokolskaya $(1973,1983)$. The spermatozeugmata were "rather broad" according to Holmquist (1985), who depicted them as pear-shaped but without any tail. Sokolskaya (1973) had drawn them as almost round. In our whole mounts, they usually looked drop-like but often had a thin "tail" from which the axial spermatozoa could be expressed (Fig. 3b). An aberrant specimen was devoid of male funnels, atria, and penes, although the vasa deferentia were observed in segment XII and the spermathecae were filled with spermatozeugmata. The local populations of $T$. americanus may be conspecific with those occurring in North America but with a different structure of the spermathecae and spermatozeugmata, as described above. The Lake Kurilskoe specimens had fewer hair chaetae per bundle than those from the other lakes of Kamchatka and those from North America. Mature specimens of Tasserkidrilus hrabei (Sokolskaya,

Fig. 3. Tubificidae from Lake Kurilskoe. a, b, Tasserkidrilus americanus; $\mathrm{c}-\mathrm{h}$, Tubificidae gen. sp. No. 1; i-r, Tubificidae gen. sp. No. 2. a, Section of spermathecal ampulla; b, spermatozeugmata; c, d, i, anterior end; e, chaeta; f, spermatheca, from cross section; g-h, q-r, two sequential cross sections with atria; $j$, anterior bundle of chaetae (dorsal and ventral ones uniform); $\mathrm{k}$, posterior dorsal bundle of chaetae; l-n, tips of anterior, posterior ventral, and posterior dorsal chaetae, respectively (drawn freehand); o, penial chaeta; $p$, part of two spermathecae, from cross section. Body segments numbered with Roman numerals in c, d, i. 

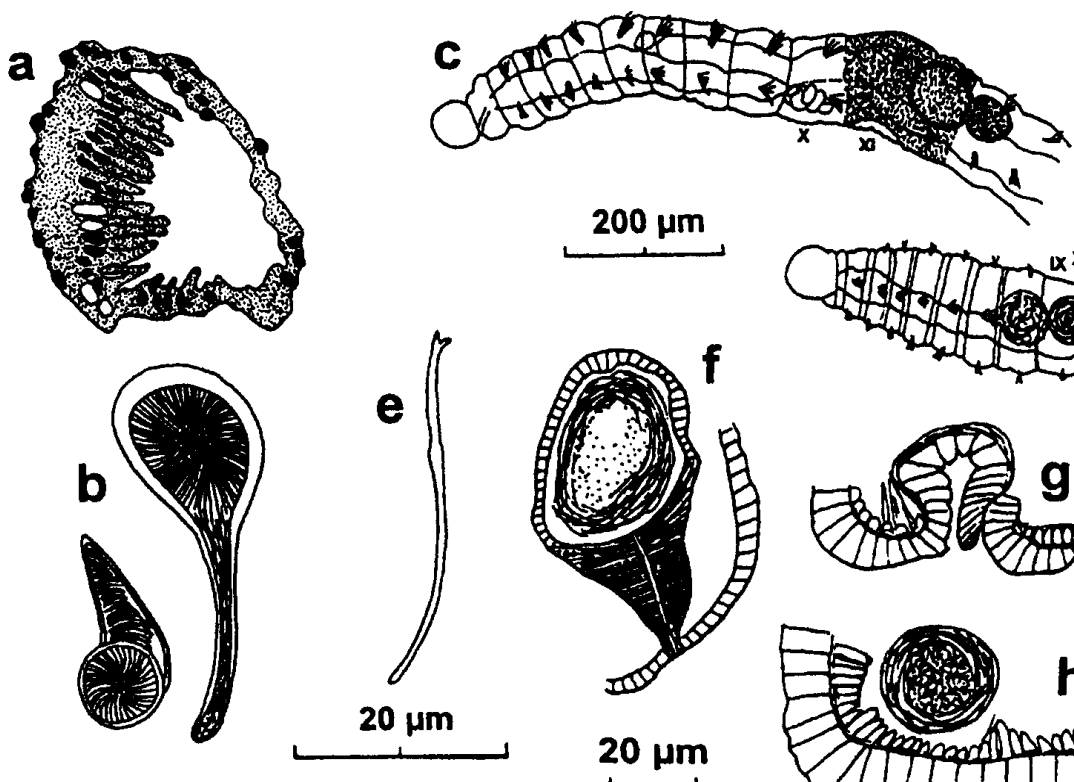

$20 \mu \mathrm{m}$
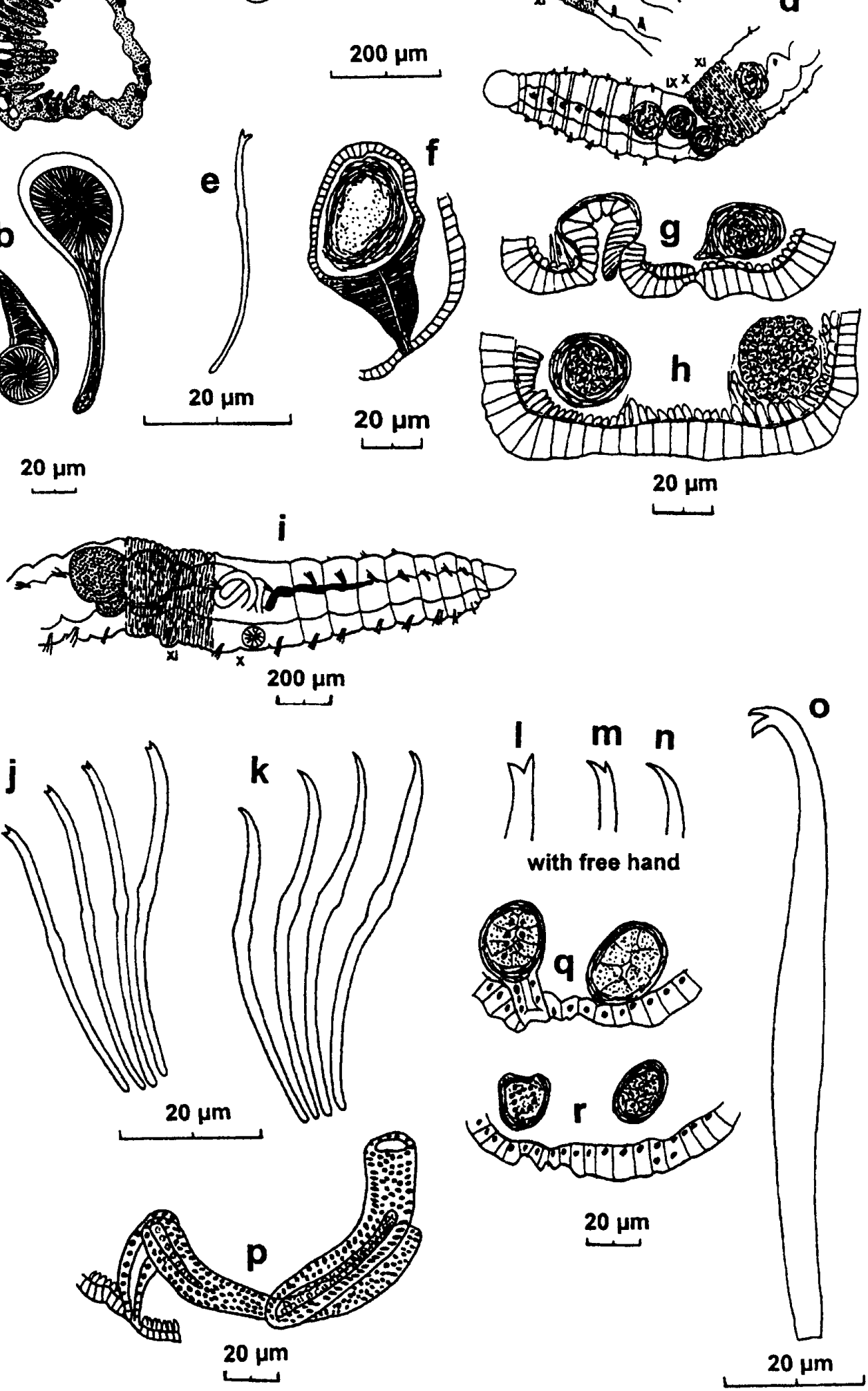
1973) (= Tubifex hrabei of Sokolskaya 1973, 1983) were collected only twice during this study. Immature specimens of $T$. hrabei may not be distinguishable from immature $T$. americanus. The number of hair chaetae seemed to be relatively low (one to two instead of three to four) in T. hrabei of Lake Kurilskoe, just as recorded for the sympatric T. americanus.

Tubificidae gen. sp. No. 1 (Fig. $3 \mathrm{c}-\mathrm{h})$ is a small $(2.5 \mathrm{~mm}$, segment number 33-38), undescribed species of the subfamily Rhyacodrilinae, with trivial bifid chaetae only, and with typical rhyacodriline atria and spermathecae. Tubificidae gen. sp. No. 2 (Fig. 3i-r), another undescribed species in the Rhyacodrilinae, was found as a single individual. Locomotory chaetae of three kinds, large penial chaetae numbering at least five to six per bundle, spermathecal pores in the anterior part of segment $\mathrm{X}$, small oval atria, and very long tubular spermathecae are characteristic of this taxon. Tubificidae No. 3 was represented by a single immature individual having only two to three bifid chaetae per bundle, all with a shorter upper tooth.

Specimens of the enchytraeid Mesenchytraeus sp. No. 1 collected during this study differed from the sympatric $M$. armatus (Levinsen, 1884) in that they were devoid of any enlarged dorsal chaetae and were more curved in body shape when preserved. The single individual of Mesenchytraeus sp. No. 2 (=Lumbricillus sp. 2 of Timm 1999a) had slightly sigmoid chaetae with an obtuse tip and thickened midsection, lobed nephridia of the Mesenchytraeus-type, long, tubular atria with detached internal epithelium and with several short side branches, an unpaired ventral egg sac, and irregular, sac-like spermathecae with a sinuous duct but no diverticula (Fig. 4b, i-m, r). The testes were distally branched but not bush-like, as previously noted by Timm (1999a). Mesenchytraeus kuril differs from its congeners in having very delicate chaetae and an extremely thick-walled spermathecal diverticulum (Fig. 4a, h).

Lumbricillus pagenstecheri (Ratzel, 1869) (=Lumbricillus sp. 1 of Timm 1999a) (Fig. 4c, d, n), the most common oligochaete collected from littoral sites in the lake and from the river during this study, was morphologically dissimilar to specimens of the mysterious Pachydrilus (=Lumbricillus) kamtschatkanus Michaelsen, 1929. The latter species was the only enchytraeid dredged from Lake Kurilskoe in 1909; Michaelsen (1929) considered it to be closely related to $P$. pagenstecheri (=L. pagenstecheri), although their spermathecae are clearly different from one another (Timm 2005). The second species of Lumbricillus in the lake, L. arenarius (Michaelsen, 1889), is distinguished from its congeners by the presence of relatively huge spermathecae and three chaetae in each of the anterior bundles (Fig. 4e, o).

Marionina charlottensis Coates, 1980 is externally similar to $M$. argentea (Michaelsen, 1889) but its spermathecae are devoid of any diverticula or glandular cover, except for a large crown of glands surrounding the external pore (Fig. 4f, p). Coates (1980) described its short spermathecal duct as "surrounded by glands of irregular size, no basal rosette"; however, her drawing of these glands can be well in-

Fig. 4. Enchytraeidae from Lake Kurilskoe. a, h, Mesenchytraeus kuril; b, i-m, r, Mesenchytraeus sp. No. 2; c, d, n, Lumbricillus pagenstecheri; e, o, L. arenarius; f, p, Marionina charlottensis; g, q, M. klaskisharum. a-g, Bundles of chaetae; $\mathrm{h}-\mathrm{q}$, spermathecae (i-m as a series of sequential sections); $r$, cross section of distal portion of atrium. 

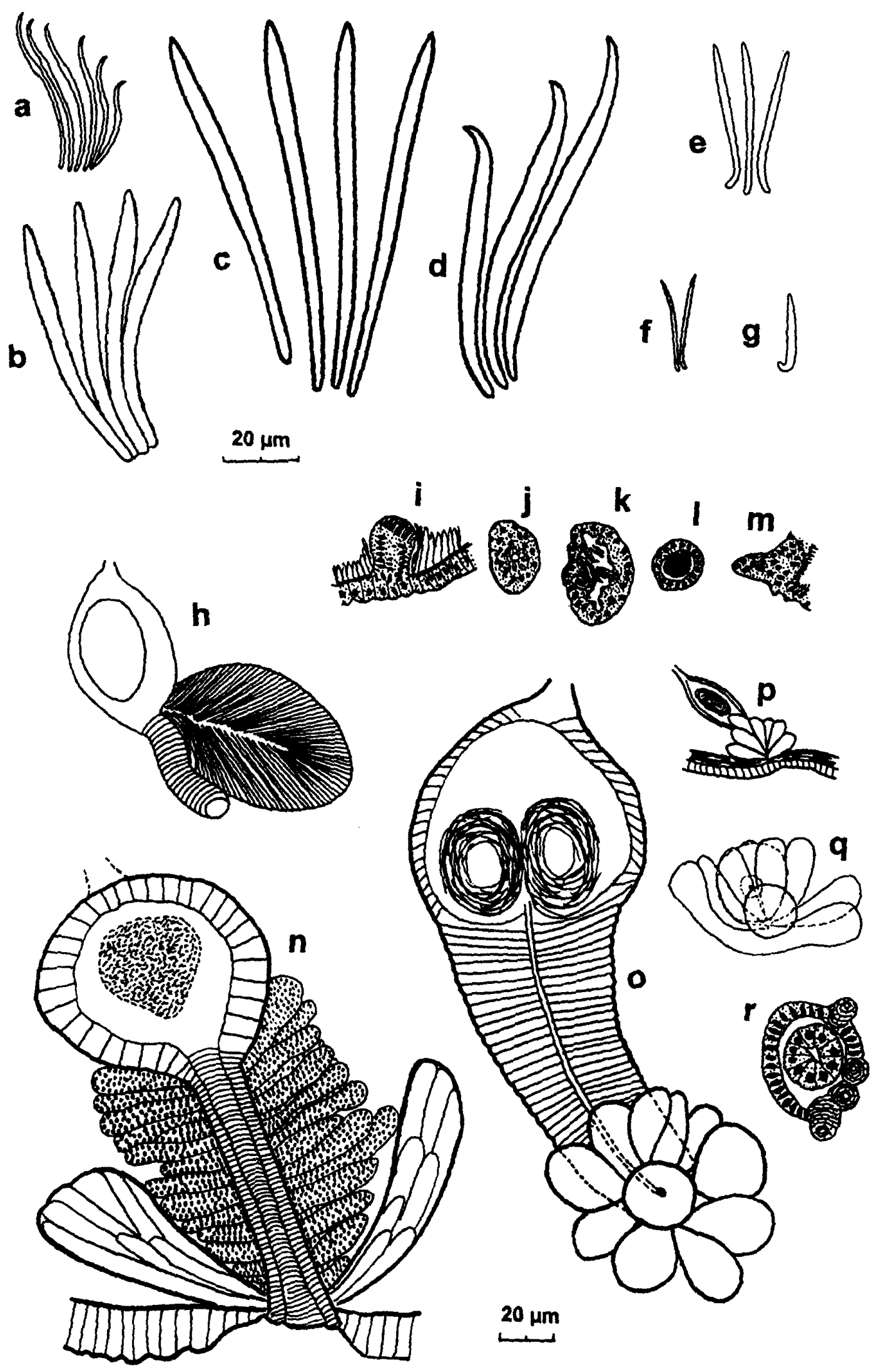
terpreted as a basal rosette-comparable to our observations in specimens collected during the present study. Specimens of Marionina klaskisharum Coates, 1983 collected here were easily recognizable by their thread-like appearance (due to long, stretched segments), and very short $(20-35 \mu \mathrm{m})$, single chaetae present only ventrally and only in segments II-V (Fig. 4g, q). In contrast to the original description (Coates 1983), specimens of this species collected during the present study had glands surrounding the ectal pore (Fig. 4q), but not the duct of the spermatheca, and the ectal portion of the ampulla was not lobed. Shurova (1979) described an externally very similar marine species, $M$. subachaeta Shurova, 1979. In the latter taxon the ectal duct of the spermatheca is densely covered with fine gland cells while the gland rosette at the pore is absent.

The lumbriculid Tatriella slovenica Hrabě, 1939 from Lake Kurilskoe corresponded to the European descriptions by Hrabĕ (1939) and Timm and Popchenko (1978). Degenerative variation, due to parthenogenesis, was apparent in the reproductive system: spermathecae and sometimes even the male ducts were lacking in some specimens with well-developed eggs. Single as well as paired spermathecae were observed, always empty and sometimes even devoid of efferent ducts. The single atrium was usually well developed.

Styloscolex opisthothecus Sokolskaya, 1969 fit the descriptions by Sokolskaya (1969, 1983) but was smaller (12-20 mm, with 41-68 segments). Two abnormal individuals were studied. One possessed an extra testis and male duct in segment VII, with the clitellum covering also segment VII; the second specimen had hypertrophied pharyngeal glands that tightly filled not only segments III-IV (as has commonly been observed in this taxon), but also segments I-II and the prostomium. This second specimen also lacked, completely, one of the spermathecal ampullae (the corresponding duct was connected with the intestine!) while the other ampulla was unusually large. Holmquist (1974) reported S. opisthothecus from two Alaskan lakes, including descriptions of the specimens. The atrial ducts in these Alaskan specimens were clearly distinguished from the ampulla and had a thick internal epithelium accreted with the muscular layer. Holmquist also mentioned the presence of blind, partially branching side blood vessels in the posterior of her specimens. No similar structure of the atrial ducts, nor any posterior side blood vessels, were observed in the Lake Kurilskoe specimens, and these discrepancies may indicate a taxonomic difference between the Kamchatkan and Alaskan populations.

Specimens of Lumbriculidae gen. sp. collected from the river and the lake littoral during this study were only $6-7 \mathrm{~mm}$ long, with about 40 segments; all chaetae possessed a minute upper tooth. Reproductive organs were often incomplete, even in mature individuals. This may be an undescribed species.

\section{Distribution among lake habitats}

The shallow littoral areas of the lake, less than $1 \mathrm{~m}$ deep and with bare stony, gravel, or sandy bottoms, were sampled most intensely. In June the oligochaete community was sparse (about 10-200 individuals $/ \mathrm{m}^{2}$ ) at all sites but increased rapidly with development of algal periphyton, particulary at two wind-protected sites near the western shore (Severnaya-Blizhnyaya and Etamynk). Oligochaete abundance there fluctuated between 5,000 and 25,000 individuals $/ \mathrm{m}^{2}$ between the end of July and the mid-September in 1998. The mean abundance for the season was 42 
7,181 individuals $/ \mathrm{m}^{2}$ for different sites, and 1,545 individuals $/ \mathrm{m}^{2}$ for all sites together. The community was usually dominated by Enchytraeidae: either Lumbricillus pagenstecheri or Mesenchytraeus kuril. The larger species, L. pagenstecheri, constituted the bulk of the oligochaete biomass in the shallowest littoral habitats; the presence of two cohorts was observed during the summer. Sometimes Propappus arhynchotus Sokolskaya, 1972 was most abundant. Several other taxa occurred here but in lower abundance. The large but always immature Haplotaxis gordioides (Hartmann, 1821) was found mostly in this shallowest zone of the lake. The most diverse fauna was observed near the outflow. In Teplaya Bay warmed by thermal springs, the tiny naidine Pristina aequiseta flourished beginning in July and often was accompanied by large numbers of Nais communis.

In the single site in the outflowing river, a similar species-rich oligochaete fauna was observed. The abundance was high: 760 individuals $/ \mathrm{m}^{2}$ in June, then increasing to 25,440 individuals $/ \mathrm{m}^{2}$ in the following months, with a mean of $5,462 \mathrm{in}$ dividuals $/ \mathrm{m}^{2}$ for the sampling season in 1998. Nais communis was collected more frequently in the river than from the lake littoral, while Uncinais uncinata, common in the river, was never collected from sites in the lake itself.

The oligochaete community of the spring brook was meagre in 1998, with 8-1,333 (mean only 426) individuals $/ \mathrm{m}^{2}$. However, 11,475 individuals $/ \mathrm{m}^{2}$ were found there once in 1994. The oligochaete fauna of the brook was almost exclusively limited to enchytraeids, but did include Propappus arhynchotus. Mesenchytraeus kuril was the dominant taxon; $M$. armatus and occasionally other terrestrial enchytraeids occurred more often here and near the outflow than at other study sites.

The deeper littoral areas, at depths of 1-5 $\mathrm{m}$ along the transect, where stones were covered with rich periphyton, revealed the most diverse fauna; different species prevailed in separate samples. Abundance fluctuated between 480 and 25,080 individuals $/ \mathrm{m}^{2}$ in different samples, with a mean of 6,807 individuals $/ \mathrm{m}^{2}$. Nais communis was often very abundant, accompanied by $N$. variabilis and $N$. pardalis. This was the main habitat for Tubificidae gen. sp. No. 1, Lumbricillus arenarius, Marionina charlottensis, $M$. klaskisharum, Tatriella slovenica, and Lumbriculidae gen. sp. Other species also common in this habitat included Limnodrilus profundicola (Verrill, 1871), Tasserkidrilus americanus, and Styloscolex opisthothecus (although all three were most characteristic of deeper habitats), as well as Propappus arhynchotus and Mesenchytraeus kuril, which were dominant in the shallowest zone.

The samples collected from the sublittoral depths (between 5 and $20 \mathrm{~m}$ ) demonstrated the greatest abundance of oligochaetes, $40-43,760$ individuals $/ \mathrm{m}^{2}$ in different cases, mean of 10,262 individuals $/ \mathrm{m}^{2}$. Nais spp. and most enchytraeids were less frequent in the sublittoral than in the littoral. Lumbricillus arenarius and Tatriella slovenica were common, together with Limnodrilus profundicola, Tasserkidrilus americanus, and Styloscolex opisthothecus.

In the profundal zone, the population density was high, 714-11,424 individuals $/ \mathrm{m}^{2}$ in different samples taken from depths of $24-198 \mathrm{~m}$ in 1997-1998 (mean 4,673 individuals $/ \mathrm{m}^{2}$ ). There was no decline in abundance with depth: the maximum, 11,424 individuals $/ \mathrm{m}^{2}$, was found at $166 \mathrm{~m}$. The profundal areas were always inhabited by Embolocephalus kurenkovi, Limnodrilus profundicola, Tasserkidrilus sp. (possibly $T$. americanus or T. hrabei, although no mature specimens were avail- 
able), and Styloscolex opisthothecus. At moderate depths (between 20 and $40 \mathrm{~m}$ ), the four species above were sometimes accompanied by several other, shallow-water species (e.g., Lumbricillus pagenstecheri, Marionina charlottensis, or Propappus arhynchotus).

\section{Other observations}

Internal parasites were observed in some oligochaetes. A mature, egg-producing caryophyllaeid cestode (Archigetes sp.?) was observed in the body cavity (segments VIII-XI) of an immature Limnodrilus profundicola. In two other specimens, the body cavity in several segments (XV-XX) was filled with sphaerical parasites of $25-50 \mu \mathrm{m}$ in diameter, each containing up to 10 nucleate cells. Two immature Tasserkidrilus americanus were infested with larvae of a caryophyllaeid cestode. Intestinal parasites were observed twice in Styloscolex opisthothecus. In one case, several roundish or oval bodies, $90-186 \mu \mathrm{m}$ wide and filled with many small cells, were observed in some segments (between segments VIII and XV). In the other individual, long, spindle-shaped ciliates occurred in segment XII.

In several cases, cocoons collected together with mature oligochaetes could be ascribed to these species (Fig. 5). The cocoons of Limnodrilus profundicola (Fig. 5a) had smooth, transparent shells and equally short, wide appendages, and each usually contained two eggs. Cocoons probably belonging to Tasserkidrilus americanus (Fig. 5b) had a slightly thinner shell and longer appendages. The cocoons of Embolocephalus kurenkovi (Fig. 5c) had short, wide appendages and a transparent shell finely encrusted with diatoms; each contained one to three eggs. Oval cocoons of Lumbricillus arenarius (Fig. 5d), with a very thin shell and rudimentary appendages, usually contained three to six eggs; these cocoons were often found in all summer months. A single cocoon of Tatriella slovenica (Fig. 5e) was collected in the river. It was large ( $3.3 \mathrm{~mm}$ long), spindle-shaped but bent, with a very thin, soft, transparent shell and rudimentary appendages, and contained 15 young worms (not all of them sketched in the figure) almost ready to hatch.

\section{Discussion}

Michaelsen (1929) recorded six oligochaete species collected from Lake Kurilskoe in 1909: Paranais naidina (Bretscher, 1896), Nais communis, Pachydrilus kamtschatkanus (described by him as a new, endemic species), Peloscolex ferox (Eisen, 1879), Lumbriculus variegatus (Müller, 1774), and Phreoryctes (=Haplotaxis) gordioides. With the exception of the enchytraeid, P. kamtschatkanus, all were dredged from the profundal depths $(50-60 \mathrm{~m})$ of the lake. The presence of N. communis, L. variegatus, and $H$. gordioides in the lake (although not specifically from the profundal) was confirmed in this study. Pachydrilus (=Lumbricillus) kamtschatkanus remains an enigma, because it was not retrieved during this present study (see also Timm 2005). Peloscolex ferox (=Spirosperma ferox Eisen, 1879, according to Holmquist 1979) was not collected during this study, and it seems to be lacking elsewhere on the Kamchatka Peninsula (Sokolskaya 1983). The Kamchatkan endemic species Embolocephalus kurenkovi (not yet been described at that time) may have been confused with $S$. ferox by Michaelsen (1929). Paranais (=Homochaeta) naidina is a non-existent, only nominal species, according to Timm and 

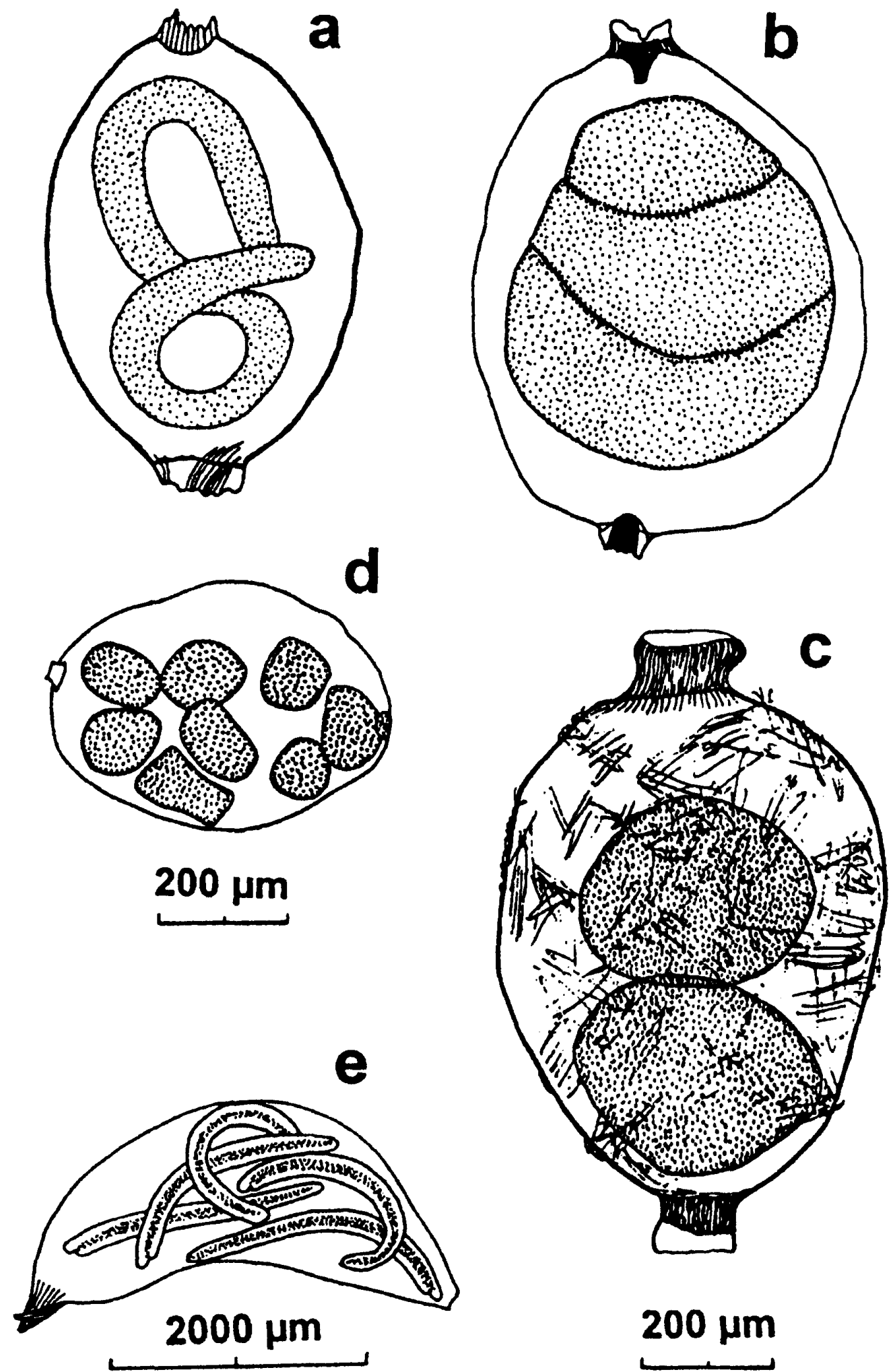

Fig. 5. Cocoons of oligochaetes from Lake Kurilskoe. a, Limnodrilus profundicola; b, Tasserkidrilus americanus; c, Embolocephalus kurenkovi; d, Lumbricillus arenarius; e, Tatriella slovenica. 
Grimm (2005). It is possible that a small, immature specimen of Limnodrilus profundicola was erroneously identified as $P$. naidina by Michaelsen (1929). Sokolskaya (1983), who treated oligochaetes collected from numerous other Kamchatkan water bodies, had no material collected from Lake Kurilskoe.

In this paper, 26 nominal species, four unnamed but probably undescribed species, and 13 other taxa identified to the genus or family level only, were reported in Lake Kurilskoe and in adjacent lotic waterbodies. Sokolskaya (1983) recorded a total of 35 species from the inland waters of Kamchatka (including the suspect Homochaeta naidina). Fifteen nominal species are common to both reports. This study (together with Healy and Timm 2000) added 11 nominal species not previously known from the Kamchatka Peninsula: Nais pseudobtusa Piguet, 1906, Chaetogaster diastrophus (Gruithuisen, 1828), Pristina aequiseta, Mesenchytraeus kuril, Henlea perpusilla Friend, 1911, Lumbricillus pagenstecheri, L. arenarius, Marionina charlottensis, M. klaskisharum, Tatriella slovenica, and Dendrobaena octaedra (Savigny, 1826). Thus the faunal list of the Kamchatkan fauna now includes 46 nominal oligochaete species (excepting the four taxa considered here to be undescribed). During this study, four genera, Amphichaeta, Cernosvitoviella, Cognettia, and Fridericia, were recorded for the first time from the Kamchatka Peninsula.

The majority of the species listed by Sokolskaya (1983) from various places of the Kamchatka Peninsula (20 of 35) were not found in Lake Kurilskoe, e.g., the otherwise widely distributed Rhyacodrilus coccineus (Vejdovský, 1876) and Embolocephalus nikolskyi (Lastochkin and Sokolskaya, 1953). This discrepancy can be explained by historical and ecological factors. The Kamchatka Peninsula is connected to the continent via a northern isthmus only. The geologically young Lake Kurilskoe is located in its most remote southern end, in a small, isolated watershed. Many widely distributed oligochaetes such as Tubifex tubifex (Müller, 1774), Limnodrilus hoffmeisteri Claparède, 1862, or Spirosperma ferox were not reported in Kamchatka by Sokolskaya (1983), nor during the present study. Thus, we believe that they have not yet reached the peninsula. Several other oligochaete species, present on the peninsula, may not yet have crossed the mountain ranges separating Lake Kurilskoe from the other freshwater basins. Also, the lack of macrovegetation and muddy shallows, and the cool summer with strong surf waves may be intolerable, e.g., for many naidines. The genus Nais is represented in Lake Kurilskoe by only four species: $N$. communis, $N$. variabilis, $N$. pardalis, and $N$. pseudobtusa. The absence of several other widely distributed species such as $N$. elinguis Müller, 1774 and $N$. barbata Müller, 1774 is surprising.

It is also noteworthy that the shallow littoral areas of this temperate lake were inhabited mostly by Enchytraeidae - similar to observations in small alpine ponds (e.g., Dumnicka and Galas 2002). The dominant taxa in this study included only one confirmed freshwater enchytraeid species, the endemic Mesenchytraeus kuril, while four others were of marine origin: Lumbricillus pagenstecheri, L. arenarius, Marionina charlottensis, and $M$. klaskisharum. None of these four species has been recorded from the north-western Pacific rim. Their presence in other Kamchatkan inland waters is possible but has not yet been established. Lumbricillus pagenstecheri has been recorded mostly from the marine littoral in many regions of the world, but not yet from the Russian Far East (Timm 2005). Several other related, near-shore marine species have been reported from here (Shurova 1974, 1977, 1978, 
1979). The nominal taxon $L$. pagenstecheri s. l. may represent a superspecies including also this form from Lake Kurilskoe (Timm 2005). Lumbricillus arenarius has been known as a marine littoral species in the North Atlantic and $M$. charlottensis and $M$. klaskisharum were described from marine littoral habitats on the opposite coast of the Pacific; thus, their occurrence in a freshwater Pacific lake is surprising. The anatomical discrepancies observed between the present specimens of $M$. klaskisharum and the original description may serve as an example of beginning speciation subsequent to entry into fresh water. The distribution of the Holarctic Mesenchytraeus armatus and other mostly terrestrial enchytraeids was limited to the spring brook and a nearby littoral site in Lake Kurilskoe.

The profundal fauna of Lake Kurilskoe was limited to four or five tubificid and lumbriculid species (the presence of Tasserkidrilus hrabei in the profundal is probable but has not yet been verified). The species composition in the profundal of Lake Kurilskoe is similar to that of the European deep oligotrophic lakes, but comprises mostly vicarious species of similar morphological types. There was one tubificid without hair chaetae (Limnodrilus profundicola, common to both regions), one with hair chaetae and a smooth (non-papillate) body [Tasserkidrilus americanus; with European counterparts Tubifex tubifex, Psammoryctides barbatus (Grube, 1861), and Potamothrix spp.], one with hair chaetae and a papillate body [Embolocephalus kurenkovi; in Europe E. velutinus (Grube, 1879) and Spirosperma ferox], and one lumbriculid [Styloscolex opisthothecus; in Europe Stylodrilus heringianus Claparède, 1862, S. lemani (Grube, 1879), and Bichaeta sanguinea Bretscher, 1900]. This parallel suite of morphologies may reflect some obscure division of resources among the profundal oligochaete community. Sokolskaya (1983) recorded Spirosperma apapillatus (Lastochkin and Sokolskaya, 1953) as common in the depths of other Kamchatkan lakes; this species seems to be lacking in Lake Kurilskoe, however, perhaps because of barriers to its dispersal.

The oligochaete fauna of the only 8000 year-old Lake Kurilskoe is not comparable with the rich endemic fauna of ancient lakes, e.g., Lake Baikal recently surveyed by Semernoy (2004). In comparison, another (although more southern) Far Eastern caldera lake, Lake Towada in Japan (Ohtaka 2001, 2004), is inhabited by considerably more naidines and other tubificids, yet fewer enchytraeids and lumbriculids, than Lake Kurilskoe. Four species inhabit the profundal of Lake Towada: Tubifex tubifex, Krenedrilus towadensis Ohtaka, 2004, Rhyacodrilus komarovi Timm, 1990 (Tubificidae), and Lumbriculus variegatus (Lumbriculidae). None of them is shared with the contemporary profundal assemblage present in Lake Kurilskoe (although $L$. variegatus had been dredged from the profundal there in 1909; see Michaelsen 1929). Neither Tubifex tubifex and Krenedrilus towadensis nor Rhyacodrilus komarovi have yet been reported from the Kamchatka Peninsula, while Lumbriculus variegatus was collected only occasionally in Lake Kurilskoe (Table 1). Thus, the species lists of both caldera lakes, and particularly their profundal zones, appear greatly dependant upon the fauna of surrounding water bodies, and can also vary in time. The absence of Lumbricillus kamtschatkanus in samples collected from Lake Kurilskoe during this present study-only 85 years after it was for the first and last time collected in 1909-is another indication of possible changes in the composition of the fauna of this lake.

The ranges of the freshwater species Tasserkidrilus americanus and Styloscolex opisthothecus reflect the past Beringian connections between the Asian 
and American continents (Timm 1999b). The amphi-Pacific ranges of the euryhaline species Marionina charlottensis and $M$. klaskisharum can also be explained by their dispersal along the Pacific coastlines, and geographical isolation may be responsible for the intraspecific morphological variation observed in the latter species. For Tasserkidrilus americanus and T. hrabei, some morphological differences are evident between the Lake Kurilskoe population and the specimens included in the original descriptions as well as other Kamchatkan populations. Both evolutionary shifts and invasions/extinctions may explain these observations.

\section{Acknowledgements}

The authors wish to thank Drs Reinmar Grimm (Hamburg) and Klara DózsaFarkas (Budapest) for valuable discussions on the taxonomy of Nais spp. and Marionina spp., respectively. We are greatly indebted to Dr T. S. Vshivkova (Vladivostok), who supervised the sampling procedures during the first year, as well as to $\mathrm{T}$. N. Travina, D. Yu. Khristova, and the late S. N. Bezrukov for their assistance with the sampling and sorting of the material. The studies by the first author were partly supported by the Core Grant 0362482s03 "Formation and changes of the biological diversity under the human impact in different lake types (Estonia-Denmark-Netherlands)" of the Estonian Ministry of Education and Research. Mrs Ester Jaigma kindly revised the English in the manuscript. Dr Mark J. Wetzel, Dr A. Ohtaka, and two anonymous reviewers greatly contributed to its comprehensibility.

\section{References}

Brinkhurst, R. O. and Cook, D. G. 1966. Studies on the North American aquatic Oligochaeta III: Lumbriculidae and additional notes and records of other families. Proceedings of the Academy of Natural Sciences of Philadelphia 118: 1-33.

Coates, K. 1980. New marine species of Marionina and Enchytraeus (Oligochaeta, Enchytraeidae) from British Columbia. Canadian Journal of Zoology 58: 1306-1317.

Coates, K. A. 1983. New records of marine Marionina (Oligochaeta, Enchytraeidae) from the Pacific Northeast, with a description of Marionina klaskisharum sp. nov. Canadian Journal of Zoology 61: 822-831.

Dumnicka, E. and Galas, J. 2002. Factors affecting the distribution of Oligochaeta in small high mountain ponds (Tatra Mts, Poland). Archiv für Hydrobiologie 156: 121-133.

Erséus, C. and Gustavsson, L. 2002. A proposal to regard the former family Naididae as a subfamily within Tubificidae (Annelida, Clitellata). Hydrobiologia 485: 253-256.

Harman, W. J. 1980. Specific and generic criteria in freshwater Oligochaeta, with special emphasis on Naididae. Pp. 1-24. In: Brinkhurst, R. O. and Cook, D. G. (Eds) Aquatic Oligochaete Biology. Plenum Press, New York and London.

Healy, B. and Timm, T. 2000. Mesenchytraeus kuril, a new species of Enchytraeidae (Annelida: Oligochaeta) from Kamčatka, Russian Far East. Species Diversity 5: 177-182.

Holmquist, C. 1974. A species of Styloscolex Michaelsen (Oligochaeta, Lumbriculidae) found in two lakes in Northern Alaska. Internationale Revue der Gesamten Hydrobiologie 59: $49-55$. 
Holmquist, C. 1979. Revision of the genus Peloscolex (Oligochaeta, Tubificidae), 2. Zoologica Scripta 8: 37-60.

Holmquist, C. 1985. A revision of the genera Tubifex Lamarck, Ilyodrilus Eisen, and Potamothrix Vejdovský \& Mrázek (Oligochaeta, Tubificidae), with extensions to some connected genera. Zoologische Jahrbücher, Abteilung für Systematik, Ökologie und Geographie der Tiere 112: 311-366.

Hrabě, S. 1939. Oligochètes aquatiques des Hautes Tatras. Věstnik Československé Zoologické Společnosti v Praze 6-7: 209-236.

Levanidov, V. Ya. 1976. [Biomass and structure of the benthic biocenoses of small streams of the Chukchi Peninsula]. Pp. 104-122. In: Levanidov, V. Ya. (Ed.) Freshwater Fauna of the Chukchi Peninsula. Dalnevostochnyi Nauchnyi Centr Akademii Nauk SSSR, Vladivostok. [In Russian]

Michaelsen, W. 1929. Oligochäten der Kamtschatka-Expedition 1908-1909. Annuaire du Musée de l'Académie des Sciences de l'URSS 30: 315-329.

Milovskaya, L. V. 2004. [General hydrochemical characterization and trophic status of Lake Kurilskoe]. Isslenovaniya Vodnykh Biologicheskikh Resursov Kamchatki i Severo-Zapadnoi Chasti Tikhogo Okeana, Sbornik Nauchnyh Trudov 7: 59-67. [In Russian]

Milovskaya, L. V., Selifonov, M. M. and Sinyakov, S. A. 1998. Ecological functioning of Lake Kuril relative to Sockeye Salmon production. North Pacific Anadromous Fish Commission Bulletin 1: 434-442.

Ohtaka, A. 2001. Oligochaetes in Lake Towada, Japan, an oligotrophic caldera. Hydrobiologia 463: 83-92.

Ohtaka, A. 2004. A new species of the subterranean genus Krenedrilus Dumnicka (Oligochaeta, Tubificidae) from the deep bottom of an oligotrophic caldera lake in Japan. Zoological Science 21: 465471.

Semernoy, V. P. 2004. Oligochaeta of Lake Baikal. Nauka, Novosibirsk, 528 pp. [In Russian with English descriptions of new species]

Shurova, N. M. 1974. Enchytraeidae of the genus Lumbricillus (Oligochaeta) from the intertidal zone of the Kurile Islands. Sbornik Rabot Instituta Biologii Morya 1: 128-136. [In Russian with English summary]

Shurova, N. M. 1977. New littoral species of the genus Lumbricillus (Oligochaeta). Biologiya Morya 1: 57-62. [In Russian with English summary]

Shurova, N. M. 1978. The intertidal oligochaets from the eastern coast of Kamchatka. Pp. 98-106. In: Kussakin, O. G. (Ed.) Litoral Beringova Morya i Yugo-Vostochnoi Kamchatki [Littoral of the Bering Sea and Southeastern Kamchatka]. Nauka, Moskva. [In Russian with English summary]

Shurova, N. M. 1979. [Enchytraeids (Oligochaeta) of the Far Eastern seas of the USSR]. Sbornik Rabot Instituta Biologii Morya 15: 75 90. [In Russian]

Sokolskaya, N. L. 1969. New species of the Lumbriculidae (Oligochaeta) from Kamchatka. Zoologicheskii Zhurnal 48: 342-349. [In Russian with English summary]

Sokolskaya, N. L. 1973. New Tubificidae species from Kamchatka and new findings of oligochaetes in the basins of the peninsula. Byulleten Moskovskogo Obshchestva Ispytatelei Prirody, Biologiya 78: 54-67. [In Russian with English summary]

Sokolskaya, N. L. 1983. [Freshwater Oligochaeta of Kamchatka and the Koryak Highlands]. Sbornik Trudov Zoologicheskogo Muzeya Moskovskogo Universiteta 22: 22-119. [In Russian]

Stepanov, V. V. 1986. [Chemical content of the water of Lake Kurilskoe]. Pp. 134-142. In: Kompleksnye Issledovaniya Ozera Kurilskogo (Yuzhnaya Kamchatka) [Complex Researches on 
Lake Kurilskoe (Southern Kamchatka)]. Izdatelstvo Dalnevostochnogo Universiteta, Vladivostok. [In Russian]

Timm, T. 1999a. Lake Kurilskoe as an enchytraeid site. Newsletter on Enchytraeidae 6: 11-14.

Timm, T. 1999b. Distribution of freshwater oligochaetes in the west and east coastal regions of the North Pacific Ocean. Hydrobiologia 406: 67-81.

Timm, T. 2005. On the distribution and taxonomical limits of Lumbricillus pagenstecheri (Oligochaeta, Enchytraeidae). Proceedings of the Estonian Academy of Sciences, Biology, Ecology 54: 292-301.

Timm, T. and Grimm, R. 2005. What is Homochaeta naidina Bretscher, 1896 (Oligochaeta, Naididae)? Zoosystema 27: 469-482.

Timm, T. and Popchenko, V. 1978. The aquatic Oligochaeta of the Murmansk Region. Pp. 71-132. In: Seasonal Phenomena in Fresh-Water Biology, Hydrobiological Researches VII. Academy of Sciences of the Estonian SSR, Institute of Zoology and Botany, Tartu. [In Russian with English summary]

Ukolova, T. K. and Sviridenko, V. D. 2002. [Annual dynamics of the oxygen and nutrients in Lake Kurilskoe in 1980-2000]. Isslenovaniya Vodnykh Biologicheskikh Resursov Kamchatki i Severo-Zapadnoi Chasti Tikhogo Okeana, Sbornik Nauchnyh Trudov 6: 7-18. [In Russian]

Vvedenskaya, T. L. and Travina, T. N. 2001. [Role of the bottom invertebrate fauna of Lake Kurilskoe in the food of the young of sockeye salmon (Oncorhynchus nerka)]. Voprosy Ikhtiologii 41: 518-524. [In Russian]

Zubin, M. I., Nikolaev, A. S. and Shejmovich, V. S. 1982. [New data on the origin of the Lake Kurilskoe depression in Kamchatka]. Vulkanologiya i Seismologiya 1: 85-88. [In Russian] 